\title{
Utilization of Virtual Community as a Communication Media For Pokemon Go Game Group (JPR) Using Social Media
}

\section{Pemanfaatan Virtual Community Sebagai Media Komunikasi Kelompok Game Pokemon Go (JPR) Melalui Media Sosial}

\author{
Yudha Pradhana ${ }^{1}$ \\ ${ }^{1}$ Departemen Ilmu Komunikasi, Universitas Indonesia, Jl. Salemba Raya No. 4, Gd. IASTH, Lt. 6, \\ Kampus UI Salemba, Jakarta Pusat 10430* \\ Email: gynpyudha@gmail,com
}

Masuk tanggal : 24-11-2020, revisi tanggal : 31-03-2021, diterima untuk diterbitkan tanggal : 19-05-2021

\begin{abstract}
Basically, humans are social creatures that can't live without interference from other humans, or it can be said that humans have the instinct to live in groups or communities. Groups or communities are formed because of shared goals and the existence of group communication between members in them. Along with advancement in technology, especially in the digital era at this time, groups or communities are not only intertwined in the real world but also in cyberspace or virtual. Virtual communities use social media to carry out group communication in it. This study aims to determine the use of virtual communities as communication media for Pokemon Go game groups in Jakarta, namely Jakarta Pogo Raiders (JPR) through social media Instagram and WhatsApp. This research uses a qualitative approach, researcher use the literature review and in-depth interviews methods with informants including initiators and members of the JPR community. The results of the study indicate that the group communication media used such as Instagram and WhatsApp groups are very effectives in delivering information between community members. The message construction conveyed through social media is understood and understood by all members of the JPR community. The success of JPR in utilizing social media as a media for group communication is marked by the comfort felt by members to remain and join the JPR community. Consciously and voluntarily they join the JPR community by taking benefits that they have gained while in that community. Another success is marked by the increasing number of community members who have joined JPR to date.
\end{abstract}

Keywords: community, group communication, Pokemon Go, social media, virtual community

\begin{abstract}
Abstrak
Pada dasarnya manusia adalah makhluk sosial yang tidak bisa hidup tanpa adanya campur tangan dari manusia lainnya, atau bisa dikatakan manusia memiliki naluri untuk hidup berkelompok atau berkomunitas. Kelompok atau komunitas terbentuk karena adanya kesamaan tujuan dan adanya komunikasi kelompok antar anggota di dalamnya. Seiring dengan berkembang pesatnya teknologi khususnya di era digital pada saat ini, kelompok atau komunitas tidak hanya terjalin di dunia nyata saja tetapi juga di dunia maya atau virtual. Komunitas virtual menggunakan media sosial untuk melakukan komunikasi
\end{abstract}


kelompok di dalamnya. Penelitian ini bertujuan untuk mengetahui pemanfaatan komunitas virtual sebagai media komunikasi kelompok game Pokemon Go yang berada di Jakarta, yaitu Jakarta Pogo Raiders (JPR) melalui media sosial Instagram dan Whatsapp. Penelitian ini menggunakan pendekatan kualitatif, peneliti menggunakan metode tinjauan pustaka dan wawancara mendalam dengan informan di antaranya penggagas dan anggota komunitas JPR. Hasil dari penelitian menunjukkan bahwa media komunikasi kelompok yang digunakan seperti Instagram dan grup Whatsapp sangat efektif dalam penyampaian informasi antar anggota komunitas. Kontruksi pesan yang disampaikan melalui media sosial tersebut dimengerti dan dipahami oleh seluruh anggota komunitas JPR. Keberhasilan JPR dalam memanfaatkan media sosial sebagai media komunikasi kelompok ditandai dengan kenyamanan yang dirasakan anggota untuk tetap berada dan tergabung di dalam komunitas JPR. Secara sadar dan sukarela mereka bergabung dengan komunitas JPR dengan memperhitungkan keuntungan yang telah didapatkan selama berada di dalam komunitas tersebut. Keberhasilan lainnya ditandai dengan semakin banyaknya jumlah anggota komunitas yang bergabung dengan JPR hingga saat ini.

Kata Kunci: komunikasi kelompok, komunitas, komunitas virtual, media sosial, Pokemon Go

\section{Pendahuluan}

Game Pokemon Go merupakan game online yang sangat diminati dan digemari oleh para pecinta game di seluruh penjuru dunia, termasuk juga bagi para gamers di Indonesia. Game yang lahir dan dirilis pada pertengahan tahun 2016 ini langsung menjadi sebuah perbincangan para gamers. Game besutan perusahaan Jepang, hasil kolaborasi yang sangat baik antara The Pokemon Company, Nintendo dan Niantic Labs ini kemudian menjadi viral dan fenomenal dari saat awal kehadirannya. Beberapa keunggulan yang disuguhkan oleh Pokemon Go, selain efek nostalgia bagi para pecinta kartun (anime) Jepang karena game tersebut merupakan adaptasi dari serial kartun Pokemon yang sempat meramaikan dunia pertelevisian Indonesia pada tahun 2000 dan menjadi tontonan favorit anak-anak pada saat itu, kemudian hal lainnya yang menjadi keunggulan adalah kemajuan teknologi yang disuguhkan terbilang baru dan sangat menarik pada game ini sehingga menjadi alasan utama game Pokemon Go menjadi fenomena di kalangan masyarakat, khususnya para pecinta game online (Lubis et al., 2019).

Kemajuan teknologi digunakan dalam game Pokemon Go ini, teknologi Geolocation dan Augmented Realty (AR) yang pada akhirnya menjadi daya tarik tersendiri sehingga banyak para penggila game memainkan game Pokemon Go dan menobatkan game ini sebagai game yang revolusioner dengan mempopulerkan teknologi tersebut. Hanya dalam waktu satu bulan, game Pokemon Go berhasil meraup 75 juta pengguna di seluruh dunia dan terus bertambah (Perdana, 2018).

Memasuki usia hampir empat tahun game Pokemon Go sejak pertama kali game ini dirilis, serta banyak game online lainnya yang bermunculan sehingga kemudian mengambil alih dominasi ranah game online dunia, tetapi Pokemon Go tetap menjadi game favorit dan termasuk yang memiliki banyak pengguna di seluruh dunia. Hingga pertengahan tahun 2019, jumlah pengguna yang mengunduh game Pokemon Go telah tembus hingga angka satu miliar pengunduh (Pratnyawan, 2019). 
Yudha Pradhana:

Utilization of Virtual Community as a Communication Media For Pokemon Go Game Group (JPR) Using Social Media

Pemanfaatan Virtual Community Sebagai Media Komunikasi Kelompok Game Pokemon Go (JPR) Melalui Media Sosial

Tabel 1: $\quad$ Unduhan Pokemon Go Secara Kumulatif Cumulative Pokémon GO downloads

$\begin{array}{ll}\text { September } 2016 & 500 \text { million } \\ \text { February } 2017 & 650 \text { million } \\ \text { July } 2017 & 750 \text { million } \\ \text { May } 2018 & 800 \text { million } \\ \text { March } 2019 & 1 \text { billion }\end{array}$

Sumber: (Iqbal, 2021)

Game Pokemon Go yang pada awalnya diprediksi dan dianggap telah habis karena banyaknya kasus negatif yang ditimbulkan oleh game ini, serta banyak pemain yang merasa bosan karena sistem yang monoton dan terpaku hanya untuk mencari dan menangkap monster Pokemon yang ada pada layar gadget, namun dengan pengembangan yang dilakukan perusahaan game ini berhasil menjaga kiprah game Pokemon Go tetap "hidup" hingga saat ini. Update yang diberikan terbilang banyak, hingga belum lama ini pengembangan yang dilakukan oleh game Pokemon Go adalah lahirnya fitur-fitur baru dan menjadi daya tarik lebih, seperti Raid, Friendship, Trading, dan Trainer Battles, yang kemudian mendorong para pengguna dalam hal ini pemain atau trainer Pokemon untuk saling bertemu dan bertatap muka secara langsung, melakukan pertarungan bersama untuk mengalahkan monster Pokemon tertentu, memulai persahabatan antar pemain atau trainer, dan juga para pemain atau trainer Pokemon dapat bertarung satu sama lain (Steverzwijn, 2019).

Update atau kebaruan fitur yang dikembangkan oleh perusahaan game Pokemon Go ini disambut dengan sangat baik oleh para gamers di seluruh penjuru dunia yang memainkan game ini, termasuk di Indonesia. Hal ini dikarenakan manusia merupakan makhluk sosial, karena pada diri dari tiap-tiap manusia terdapat dorongan untuk berhubungan atau melakukan interaksi dengan manusia lainnya. Interaksi yang dilakukan oleh manusia pada umumnya disebut interaksi sosial. Interaksi sosial secara harfiah dapat diartikan sebagai hubungan timbal balik sosial yang dilakukan manusia secara dinamis.

Hal ini yang membuat para gamers atau pemain game Pokemon Go yang pada awalnya hanya bermain secara individu untuk mencari dan menangkap monster Pokemon dengan gadget mereka masing-masing, kini muncul permasalahan dalam mengumpulkan para pemain untuk dapat bermain Pokeon Go di waktu dan tempat yang sama. Demi untuk dapat menikmati fitur-fitur baru yang disuguhkan oleh game Pokemon Go tersebut, maka para pemain berinisiatif untuk membuat suatu kelompok, grup, atau komunitas virtual. Kesamaan minat pada game Pokemon Go ini yang menjadi alasan para pemain untuk membuat komunitas virtual agar dapat dengan mudah melakukan mobilitas dalam hal permainan ini secara bersama-sama. 
Media sosial menjadi wadah bagi para komunitas virtual dalam mengumpulkan anggota-anggota komunitas dengan minat yang sama. Media sosial juga menjadi sumber suatu komunitas virtual untuk memberikan informasi dan update terbaru untuk para anggota komunitas. Media sosial juga digunakan oleh komunitas virtual game Pokemon Go untuk menginformasikan kegiatan-kegiatan sekaligus update berita terbaru mengenai game tersebut, di antaranya melalui media sosial Instagram dan Whatsapp.

Dalam penelitian ini, peneliti mengambil contoh sebuah komunitas virtual pemain Pokemon Go di kawasan Jakarta, komunitas ini bernama Jakarta Pogo Raiders (JPR). Para pemain Pokemon Go yang berdomisili atau bekerja di kawasan Jakarta menjadikan JPR sebagai wadah mereka untuk melakukan segala macam interaksi di dalam komunitas ini menggunakan media sosial seperti Whatsapp dan Instagram, informasi terkini dan jadwal bertemu untuk melakukan pertarungan melawan Pokemon monster menjadi suatu hal yang wajib diperbincangkan di dalam komunitas virtual ini.

Berdasarkan pada permasalahan yang telah dijabarkan, penelitian ini dilakukan dengan tujuan untuk mengetahui bagaimanakah peran media sosial terhadap pembentukan komunitas virtual di kalangan para pemain game Pokemon Go dalam hal ini, anggota dari komunitas virtual Jakarta Pogo Raiders (JPR), dan bagaimanakah pemain Pokemon Go yang merupakan anggota dari Jakarta Pogo Raiders (JPR) melakukan interaksi sosial dan manfaat yang didapatkan oleh para pemain secara individu yang memang tergabung di dalam komunitas virtual Pokemon Go di media sosial.

Komunitas (Pyrko et al., 2017) merupakan sekumpulan dari orang-orang yang saling dan ingin berbagi di antaranya masalah, perhatian atau kegemaran terhadap suatu hal ataupun topik sehingga menimbulkan atau membuat orang-orang yang ada di dalamnya dapat memperdalam tidak hanya dalam hal pengetahuan namun juga keahlian mereka dengan saling melakukan interaksi secara mendalam dan terus-menerus.

Seiring dengan kemajuan teknologi khususnya dalam bidang komunikasi, gagasan mengenai arti dari sebuah komunitaspun akhirnya mengalami perkembangan. Perkembangan yang dialami berdasarkan kemajuan teknologi komunikasi, muncul sebuah istilah baru dari komunitas yang dinamakan komunitas virtual. Keberadaan internet (Permassanty \& Muntiani, 2018) kini telah dijadikan sebuah media bagi individu dalam melakukan interaksi sampai kepada pelibatan emosi dalam suatu interaksi secara virtual. Pelibatan adanya emosi dalam suatu interaksi yang dilakukan secara virtual tersebut yang menjadi penyebab atau cikal bakal terbentuknya komunitas virtual. Kemunculan media baru yang disebut internet hingga maraknya bermunculan media sosial saat ini tidak hanya memberikan kesempatan bagi individu untuk melakukan interaksi yang lebih dekat dengan relasi atau individu lainnya namun juga menjadi suatu medium dalam membentuk sebuah komunitas virtual. Pengertian komunitas virtual (Prasetyo \& Irwansyah, 2020) merupakan sebuah kelompok atau komunitas yang memang secara sengaja didirikan oleh sekumpulan orang-orang yang dalam sadar memiliki kepentingan-kepentingan yang sama di antara satu dengan yang lainnya, seringkali kepentingan yang sama bagi kelompok ini biasanya berkisar pada seputar teks atau 
Yudha Pradhana:

Utilization of Virtual Community as a Communication Media For Pokemon Go Game Group (JPR) Using Social Media

Pemanfaatan Virtual Community Sebagai Media Komunikasi Kelompok Game Pokemon Go (JPR) Melalui Media Sosial

ungkapan tertentu yang menjadi suatu kesamaan yang diambil dari tempat-tempat yang mereka sukai.

Komunikasi yang dilakukan bersifat komunikasi virtual atau disebut dengan virtual communication, yaitu sebuah proses komunikasi (penyampaian dan penerimaan suatu pesan) yang bersifat interaktif melalui dunia maya atau dunia virtual. Dalam hal ini, komunitas virtual tidak dapat lepas atau melupakan peran internet sebagai ruang mereka untuk berinteraksi satu sama lain dalam komunitas tersebut.

Semua orang dapat dengan bebas membuat dan mendirikan sebuah komunitas virtual dan dengan tujuan serta keperluan apapun, seperti halnya komunitas virtual yang dibuat untuk menjalin hubungan dan komunikasi antar manusia atau individu, kemudian juga untuk mendapatkan informasi, serta untuk mengadakan transaksi antar individu dalam komunitas virtual tersebut (Prayugo, 2018).

Sama halnya dengan komunitas yang ada pada umumnya di dalam dunia nyata, komunitas virtual juga memiliki ciri-ciri sebagai suatu komunitas, yang dibangun dan dibentuk atas dasar kesamaan pada minat ataupun hobi, interaksi yang dilakukan secara teratur, identitas, fokus kepada hal yang diminati, integrasi antar anggota, serta keterbukaan dalam akses mendapatkan informasi (Hidayanti \& Yahya, 2017).

Begitu juga dengan komunitas virtual yang dibentuk oleh para pemain game Pokemon Go dari Jakarta Pogo Raiders (JPR), merupakan sebuah komunitas yang mana kesamaan dalam hal bermain game Pokemon Go menjadi landasan mereka berkumpul di dunia maya atau virtual, dengan tujuan yang sama serta memiliki interaksi di antara para anggota komunitas. Interaksi pun dilakukan secara mengalir di dalamnya, fokus pada segala macam update mengenai game Pokemon Go serta adanya integrasi yang dilakukan para anggota di dalamnya menjadi ciri dari komunitas virtual JPR. Akses informasi yang diberikan juga terbuka di dalam komunitas ini, seluruh anggota JPR berhak mendapatkannya tanpa terkecuali.

Dalam sebuah komunitas, baik itu komunitas di dunia nyata maupun komunitas virtual, terdapat komunikasi yang dilakukan oleh seluruh anggota yang ada dalam kelompok tersebut. Komunikasi yang memang sengaja dilakukan baik secara langsung maupun tidak langsung, verbal maupun non-verbal yang dilakukan di dalam kelompok disebut juga dengan komunikasi kelompok. Kelompok merupakan sekumpulan individu yang pada dasarnya memiliki tujuan yang sama dan melakukan interaksi dengan individu lainnya demi tercapai suatu tujuan secara bersama, mengenal antara satu dengan yang lainnya, serta memandang individu lainnya sebagai bagian dari kelompok tersebut (Tutiasri, 2016).

Komunikasi kelompok yang dilakukan pada saat ini berbeda dengan komunikasi kelompok pada beberapa masa yang lalu, saat ini merupakan sebuah era dimana media yang digunakan dalam proses komunikasi berganti dari media analog menjadi media yang bersifat digital. Media digital merupakan nama lain dari sebuah istilah yaitu media baru. (Situmorang, 2012) menjelaskan bahwa media digital atau media baru merupakan media yang di dalamnya terdapat gabungan dari berbagai macam konten, mulai dari teks atau tulisan, kemudian suara, serta berbagai 
jenis gambar yang kemudian dijadikan satu kesatuan dan disimpan dalam format digital.

Keberadaan media baru juga menjadi keuntungan bagi komunitas virtual JPR dalam berinteraksi bagi para anggota di dalamnya, kemudahan berinteraksi secara online membuat proses mengalirnya dan timbal baliknya suatu informasi menjadi cepat dan lancar. Setiap anggota bebas dan berhak memberikan serta menerima informasi atau update terkini dari game Pokemon Go yang menjadi fokus utama dalam komunitas ini. Kemajuan teknologi khususnya di bidang komunikasi dan informasi seperti inilah yang menjadi hal yang positif bagi kehidupan manusia setiap harinya tidak terkecuali bagi komunitas virtual seperti JPR ini.

Media sosial adalah bentuk komunikasi elektronik, yang mana pengguna dapat membuat komunitas secara online untuk saling berbagi informasi, pesan, ide, personal message dan konten lain (seperti gambar, audio dan video) (Edosomwan et al., 2011). Pada media sosial, penggunanya pun dapat melakukan berbagai macam pertukaran dalam hal apapun, bahkan kolaborasi sekalipun, serta dapat saling berkenalan dalam bentuk tulisan atau simbol yang dapat dilihat atau secara visual maupun yang dapat dilihat dan didengarkan sekaligus atau audiovisual. Sebagai contoh di antaranya seperti Blog, Twitter, Foursquare, Facebook, Instagram, Whatsapp, dan media lainnya. Hingga saat ini, Whatsapp dan Instagram adalah contoh media sosial yang sangat digemari dan termasuk yang paling banyak diakses oleh manusia dalam "berselancar" di dunia maya atau virtual. Bagi komunitas virtual JPR, Instagram dan Whatsapp juga menjadi media mereka untuk berbagi informasi dan update terbaru tentang game Pokemon Go, serta menjadi media bagi para anggota di dalamnya untuk berinteraksi secara intens satu sama lain.

Keberadaan media baru telah memenuhi banyak kebutuhan manusia yang tidak saja dapat dirasakan secara nyata, tetapi juga memenuhi kebutuhan manusia yang hanya dapat dilihat, dinikmati, dan dikonstruksi menjadi masyarakat atau komunitas yang baru, yaitu masyarakat atau komunitas maya. Komunitas maya juga bisa disebut dengan cyber community, dan pada akhirnya melahirkan sebuat teori yaitu teori cyber community. Sebuah teori komunikasi yang terdapat dalam sebuah proses komunikasi yang dilakukan di dunia maya dan tercipta paling akhir dalam pengembangan ilmu komunikasi (Rohayati, 2017). Teori yang menekankan kepada kelompok sosial yang melakukan interaksi sosial serta menghadirkan sebuah perkembangan antar anggota kelompok di dalam dunia maya atau yang biasa disebut dengan komunitas virtual. Bagaimana terciptanya komunitaskomunitas virtual, bagaimana proses komunikasi dari komunitas virtual berjalan, dan bagaimana komunitas virtual mengontruksikan pesan bagi para anggota komunitasnya. Teori ini akan membantu peneliti menjelaskan bagaimana komunitas virtual yang dibentuk para pemain Pokemon Go akhirnya tercipta di dalam komunitas JPR, bagaimana proses komunikasi di dalamnya, serta bagaimana konstruksi pesan yang digunakan melalui media sosial yang digunakan.

Satu lagi teori yang dipilih peneliti untuk menyempurnakan penelitian ini adalah teori pertukaran sosial. (Muhammad \& Manalu, 2017) menjelaskan bahwa teori pertukaran sosial menitikberatkan pada kelompok atau suatu komunitas dengan menggunakan sebuah konsep, yaitu konsep ekonomi yang di antaranya 
adalah imbalan (reward) dan biaya atau pertukaran (cost) pada suatu interaksi di dalam kelompok. Teori ini memiliki sebuah pemikiran atau asumsi bahwa seseorang atau individu pada dasarnya akan secara sadar dan sukarela untuk masuk dan menetap dalam sebuah atau suatu interaksi sosial namun sebagai catatan yaitu dengan melakukan pertimbangan mengenai segala konsekuensi atau akibat yang nantinya akan terjadi, tidak lain dan tidak bukan adalah pertimbangan antara adanya keuntungan dan juga adanya kerugian. Teori pertukaran sosial ini dapat dijadikan peneliti untuk mengetahui mengapa para anggota komunitas virtual game Pokemon Go ini tetap bertahan, apakah ada hal yang menjadi pertimbangan tiap-tiap individu dari komunitas tersebut.

Sebelum masuk kepada metode penelitian, pada kesempatan kali ini peneliti akan menjabarkan mengenai beberapa penelitian terdahulu yang menjadi acuan peneliti untuk membuat dan menyusun penelitian ini. Beberapa penelitian yang menjelaskan tentang perilaku komunikasi kelompok atau komunitas virtual sudah banyak dilakukan dengan banyak objek penelitian yang beragam, penelitian yang peneliti pilih sebagai acuan di antaranya penelitian (Muhammad \& Manalu, 2017) dalam sebuah jurnal Universitas Diponegoro dengan judul "Analisis Pemanfaatan Virtual community sebagai Media Komunikasi Kelompok melalui Media Sosial” mengungkapkan bahwa terdapat faktor yang memengaruhi individu untuk bertahan dan memanfaatkan ketergabungannya dalam kelompok virtual di media sosial.

Penelitian terdahulu lainnya adalah penelitian (Hidayanti \& Yahya, 2017) dalam sebuah jurnal ilmiah mahasiswa Universitas Syiah Kuala dengan judul "Peran Media Baru dalam Membentuk Komunitas Virtual" dengan kesimpulan bahwa proses dari terbentuknya suatu komunitas virtual didasari oleh minat serta hobi yang sama dari masing-masing anggota komunitasnya. Komunitas virtual membutuhkan media sosial untuk dapat melakukan kegiatan serta berkreativitas secara bersama-sama dengan seluruh anggota komunitas.

\section{Metode Penelitian}

Penelitan ini menggunakan pendekatan kualitatif dengan menggunakan metode tinjauan pustaka dan wawancara (interview). Seharusnya penelitian ini juga akan dilakukan menggunakan metode observasi (observation) tetapi karena masih adanya pandemi Covid-19, maka peneliti mengurungkan niat untuk melakukan metode tersebut.

Metode tinjauan pustaka ini dilakukan peneliti untuk mengumpulkan data yang dapat menjelaskan konsep mengenai komunitas virtual, media baru, serta media sosial serta beberapa teori yang mendukung dan menjadi penyempurna bagi penelitian ini. Tinjauan pustaka merupakan suatu cara untuk menemukan, mencari artikel-artikel, buku-buku dan sumber-sumber lain seperti tesis, disertasi, prosiding, yang relevan pada suatu isu tertentu atau teori atau riset yang menjadi ketertarikan penulis (Utami, 2015).

Secara singkat, (Rahayu et al., 2019) menambahkan tinjauan pustaka merupakan langkah awal menuju proses penelitian berikutnya. Sebuah metode yang sistematis, eksplisit dan juga reprodusibel untuk melakukan suatu verifikasi, evaluasi serta sintesis terhadap karya dari hasil penelitian dan hasil pemikiran yang 
dihasilkan oleh para peneliti ilmiah. Tinjauan pustaka juga bertujuan untuk dapat membuat suatu analisis dan sintesis mengenai suatu pengetahuan yang sudah ada sebelumnya terkait topik yang akan dibahas untuk menemukan suatu ruang kosong yang dapat dijadikan penelitian selanjutnya yang akan datang.

Sumber data yang didapatkan oleh peneliti di antaranya dari beberapa penelitian terdahulu yang membahas mengenai tema yang sejenis, beberapa jurnal yang sudah terpublikasi, artikel ilmiah, serta berita-berita yang diperoleh melalui internet sebagai data pendukung untuk melengkapi penelitian tersebut.

Peneliti menggunakan pendekatan kualitatif dengan analisis deskriptif. Dalam menentukan sebuah sampling penelitian, peneliti menggunakan teknik purposive sampling. Sugiyono (Astutir \& Lestari, 2019) mendefinisikan purposive sampling meriupakan suatu teknik pengambilan sampel sebagai sumber data dengan pertimbangan tertentu, karena tidak semua sampel memiliki kriteria yang sesuai dengan fenomena yang diteliti. Oleh karena itu, peneliti memilih teknik purposive sampling dengan menetapkan berbagai pertimbangan atau dan juga kriteria tertentu yang harus dipenuhi oleh sampel yang digunakan dalam penelitian ini. Dalam prosedur menentukan sampling pada dasarnya adalah bagaimana peneliti menentukan key informan dan informan. Peneliti menentukan satu orang anggota komunitas JPR bernama Lili, seorang karyawati di sebuah Lembaga independen, yang juga merupakan salah satu pencetus dan pendiri dari komunitas JPR sebagai key informan. Kemudian peneliti juga menentukan dua orang informan anggota komunitas JPR bernama Daneal, seorang karyawan swasta, dan Fajar juga seorang karyawan swasta. Peneliti melakukan wawancara secara mendalam terhadap key informan dan informan dari penelitian ini. Menurut (Hakim, 2013) bahwa wawancara merupakan situasi saling berhadapan antara peneliti dengan informan yang dimaksudkan untuk dapat menggali sebanyak-banyaknya informasi yang diharapkan, serta bertujuan untuk mendapatkan data mengenai informan dengan meminimalisir bias dan memaksimalkan efisiensi. Sementara (Linarwati et al., 2016) menambahkan bahwa wawancara merupakan suatu alat untuk melakukan re-checking atau sebuah pembuktian mengenai informasi yang telah diperoleh sebelumnya. Wawancara yang biasanya digunakan di dalam sebuah penelitian kualitatif adalah wawancara mendalam (in-depth interview), yang merupakan proses memperoleh suatu keterangan yang bertujuan untuk sebuah kepentingan penelitian dengan cara melakukan tanya jawab seraya melakukan tatap muka antara peneliti atau pewawancara dengan informan atau yang diwawancarai, dengan ataupun tanpa menggunakan adnya pedoman (guide) dari wawancara, peneliti dan informan biasanya sudah terlibat cukup lama pada suatu kehidupan sosial. Wawancara dilakukan pada 26-28 Mei 2020 dan peneliti memanfaatkan kemajuan teknologi dalam melakukan wawancara terhadap beberapa informan dengan menggunakan online chatting untuk mempermudah peneliti melakukan kontak tanpa mengganggu kesibukan informan. Alasan lain yang dijadikan peneliti dalam menggunakan online chatting adalah masih adanya wabah pandemik Covid-19 sehingga peneliti melakukan social distancing untuk memutus mata rantai penyebaran wabah tersebut sesuai dengan arahan pemerintah. 
Yudha Pradhana:

Utilization of Virtual Community as a Communication Media For Pokemon Go Game Group (JPR) Using Social Media

Pemanfaatan Virtual Community Sebagai Media Komunikasi Kelompok Game Pokemon Go (JPR) Melalui Media Sosial

\section{Hasil Penemuan dan Diskusi}

Pada era yang mana telah memasuki era digital seperti sekarang ini, perkembangan teknologi komunikasi dan informasi telah memberikan dampak dan juga perubahan yang besar bagi kehidupan manusia. Setiap individu dapat melakukan interaksi dengan individu lainnya melalui internet bahkan hingga dapat membuat sebuah perkumpulan atau kelompok secara virtual. Perkembangan komunitas virtual khususnya di Indonesia saat ini tumbuh dan berkembang dengan sangat pesat. Banyak kelompok dengan kesamaan yang bermacam-macam untuk membentuk suatu komunitas virtual secara besar-besaran termasuk komunitas virtual yang dibentuk oleh para pemain dari game Pokemon Go, salah satunya komunitas virtual Jakarta Pogo Raiders atau lebih dikenal dengan nama JPR. Sesuai dengan namanya, komunitas ini terbentuk atas dasar kesamaan akan hobi dan minat terhadap Pokemon Go yang mana para anggotanya berdomisili ataupun yang bekerja di Jakarta.

Komunitas JPR merupakan sebuah komunitas lokal di kota Jakarta yang memang sengaja dibentuk oleh para pemain Pokemon Go. Komunitas JPR dibentuk sejak tahun 2017 lalu, dengan hanya diawali beberapa anggota saja. Seiring perkembangannya, keberadaan JPR mendapatkan respon dan tanggapan yang baik di kalangan para gamers Pokemon Go, terbukti hingga kini komunitas JPR sudah memiliki lebih dari 200 orang anggota yang bergabung.

\section{Peran Media Sosial Terhadap Pembentukan Komunitas Virtual}

Komunitas JPR menggunakan media sosial dalam melakukan komunikasi kelompok, media sosial yang digunakan di antaranya adalah Instagram dan Grup Whatsapp. Kedua media sosial tersebut digunakan sebagai media atau sarana untuk melakukan komunikasi antar anggota di dalam komunitas, selain itu penggunaan media sosial tersebut oleh komunitas JPR juga memiliki tujuan untuk menyebarluaskan dan update informasi dan segala macam hal mengenai Pokemon Go serta kegiatan yang dilakukan anggota komunitas secara bersama-sama seperti melakukan pertempuran monster Pokemon Go atau biasa disebut dengan istilah Raid di dalam game tersebut. Instagram dan grup Whatsapp digunakan sebagai cara atau media alternatif di dalam komunitas JPR untuk dapat mengirimkan pesan berupa foto, video, dan teks secara langsung kepada anggota lainnya tanpa harus melakukan tatap muka. Interaksi sosial dalam hal komunikasi kelompok di dalam komunitas JPR terus dilakukan oleh seluruh anggota kelompok memberikan perkembangan terutama dalam informasi dan update mengenai game Pokemon Go yang menjadi minat atau hobi mereka Bersama. Peran media sosial terhadap pembentukan komunitas virtual tersebut dibuktikan berdasarkan pengakuan Lili, salah seorang inisiator dari komunitas JPR.

"Peran media sosial menurut aku sangat membantu sampai akhirnya JPR dikenal banyak orang, anggota JPR juga sekarang udah banyak banget."

Hal tersebut dapat memberikan penjelasan bahwa keberadaan media sosial merupakan salah satu faktor terpenting dalam pembentukan komunitas virtual JPR, media yang dijadikan wadah untuk bertukar informasi secara virtual atau maya 
ketika mereka tidak dapat bertemu secara langsung. Serta dapat dikatakan bahwa adanya komunitas virtual sebagai syarat sebuah media sosial, dimana komunitas adalah kumpulan manusia yang saling terhubung atas kesamaan tertentu.

\section{Interaksi Sosial Pada Kelompok Virtual Melalui Media Sosial \\ Teori Cyber Community}

Teori ini menjelaskan bahwa komunitas di dalam dunia maya terbentuk dari sekumpulan anggota atau individu dalam sebuah jaringan internet yang memang terjalin pada dasarnya atas motif tertentu di antaranya seperti kesamaan dalam hal hobi, kebutuhan, cara pandang, serta kesamaan latar belakang seperti profesi, pendidikan, agama, budaya, dan sebagainya. Kemudian pada akhirnya teori ini muncul dikarenakan kajian mengenai perkembangan teknologi informasi dan telematika menjadi sangat penting dan mendesak terutama dalam hal yang berhubungan dengan suatu perkembangan yang lahir dari adanya media baru. Teori ini juga menyebutkan bahwa interaksi sosial yang dilakukan kelompok di dunia maya menghadirkan sebuah perkembangan antar anggota kelompok di dalamnya. Dalam dimensi teori cyber community, disebutkan di antaranya mengenai bagaimana terciptanya komunitas-komunitas virtual. Kesamaan minat atau hobi terhadap game Pokemon Go menjadi hal yang mendasar terkait cikal bakal atau awal terciptanya komunitas JPR, komunitas ini juga terbentuk karena adanya kesamaan domisili atau tempat yang sama dimana para anggotanya menetap atau bekerja di Jakarta. Media sosial juga memiliki peran yang sangat penting dalam pembentukan komunitas JPR ini, media sosial seperti Instagram dan grup Whatsapp digunakan untuk memudahkan para pemain pokemon Go menemukan keberadaan komunitas JPR. Dimensi tersebut terbukti dengan pengakuan dari Lili tentang bagaimana terciptanya komunitas JPR.

"Jakarta Pogo Raiders terbentuk pada 1 Juli 2017, kebetulan aku sebagai salah satu penggagasnya. JPR awalnya terbentuk karena adanya sistem raid di Pokemon GO yang membutuhkan pemain lebih dari I sehingga membutuhkan media untuk bertemu, supaya bisa kumpul dan ngeraid bareng, karena hobi kita kan sama sebagai pemain Pokemon Go. Jadi kenapa ga, buat dikumpulin?"

Dimensi lainnya dari teori cyber community yaitu bagaimana proses komunikasi kelompok berjalan di dalam komunitas virtual. Proses komunikasi berjalan dengan sangat baik di dalam komunitas JPR, baik itu menggunakan media sosial Instagram maupun grup Whatsapp, hal ini ditandai dengan adanya komunikasi timbal balik yang dilakukan oleh seluruh anggota komunitas JPR. Penggunaan media sosial menjadi media yang tepat dalam melakukan proses komunikasi di dalam komunitas JPR, kemudahan akses dan keterbukaan dalam melakukan jajak pendapat bagi tiap anggota komunitas JPR dengan menggunakan media sosial yang menjadi pendorong terciptanya keberhasil proses komunikasi kelompok tersebut. Dimensi tersebut terbukti dengan pengakuan dari Daniel mengenai proses komunikasi kelompok berjalan.

"Seru, seru banget. Informasi yang dikasih lengkap, tiap ada pertanyaan atau masukan yang anggotanya kasih walaupun anak baru tetap direspon." 
Yudha Pradhana:

Utilization of Virtual Community as a Communication Media For Pokemon Go Game Group (JPR) Using Social Media

Pemanfaatan Virtual Community Sebagai Media Komunikasi Kelompok Game Pokemon Go (JPR) Melalui Media Sosial

Hal senada juga disampaikan oleh Fajar, bagaimana proses komunikasi kelompok di dalam grup Whatsapp dari JPR berjalan dengan baik.

"Gua selama bergabung di komunitas ini ngerasa nyaman, alur komunikasinya juga lancar, tiap hari pasti ada aja yang dibahas di grup Whatsapp."

Dimensi terakhir dalam teori cyber community yaitu bagaimana media kelompok mengkonstruksi pesan antar anggota di dalam komunitas virtual. Media kelompok yang digunakan seperti Instagram dan grup Whatsapp sangat efektif dalam penyampaian informasi antar anggota komunitas. Kontruksi pesan yang disampaikan melalui media sosial tersebut dimengerti dan dipahami oleh seluruh anggota komunitas JPR. Instagram dan grup Whatsapp digunakan komunitas JPR mulai dalam menyapa anggota komunitas serta juga melakukan interaksi secara langsung di dalamnya. Melalui Instagram, komunitas JPR dapat melakukan konstruksi pesan yang dilihat dengan saling mengikuti antar akun anggota komunitas, kemudian dengan anggotaikan tanda suka, memberikan komentar, serta dapat mengirim pesan secara langsung melalui fitur direct message pada Instagram. Konstruksi pesan juga dilakukan melalui grup Whatsapp yang terbilang lebih aktif karena selalu ada informasi terbaru dan ter-update setiap harinya di dalam grup tersebut. Kontruksi pesan dapat dilihat dengan timbal balik yang juga dilakukan oleh anggota komunitas lain di dalamnya, adanya komunikasi dua arah yang terjadi menunjukkan bahwa konstruksi pesan yang disampaikan dimengerti dan dipahami maknanya oleh seluruh anggota komunitas. Hal ini dibuktikan dengan pernyataan Fajar terkait dapat dipahaminya kontruksi pesan yang disampaikan di dalam media kelompok yang digunakan JPR.

"Menurut gua sih kontruksi pesan di dalam JPR sejauh ini lancar jaya, tiap anggota ngerti apa yang dibahas tiap harinya, ga ada yang missed. Instagram selalu update, nah apalagi grup Whatsapp."

Media sosial sangat penting bagi komunitas virtual dalam membangun komunikasi kelompok terhadap sesama anggota di dalamnya. Hal ini senada dengan yang disampaikan Daniel mengenai pentingnya media sosial bagi komunitas JPR.

"Menurut saya peran media sosial penting banget, biasanya orang kan kalo pake media sosial pasti lebih cepat paham dan tiap hari orang pasti gunain media sosial."

\section{Teori Pertukaran Sosial}

Keberhasilan komunitas virtual Jakarta Pogo Raiders dalam memanfaatkan media sosial sebagai media komunikasi kelompok dapat terlihat dengan keberhasilan komunitas JPR untuk tetap menjaga keutuhan anggotanya sehingga dapat bertahan di dalam komunitas tersebut. Seperti yang dijabarkan dalam teori pertukaran sosial bahwa seseorang atau individu pada dasarnya akan secara sadar dan sukarela untuk masuk dan menetap dalam sebuah atau suatu interaksi sosial namun sebagai catatan yaitu dengan melakukan pertimbangan mengenai segala konsekuensi atau akibat yang nantinya akan terjadi, tidak lain dan tidak bukan adalah pertimbangan antara adanya keuntungan dan juga adanya kerugian. Sudut pandang teori ini berpendapat bahwa orang menghitung nilai keseluruhan dari sebuah hubungan dengan mengurangkan pengorbanannya dari penghargaan yang diterima. Dalam komunitas JPR, setiap anggotanya merasa sadar dan dengan secara 
sukarela untuk tetap berada pada komunitas virtual JPR dalam waktu yang lama ke depannya karena mereka menganggap dan menilai bahwa mereka mendapatkan manfaat dan keuntungan yang lebih banyak ketimbang biaya yang mereka keluarkan selama bergabung dengan komunitas JPR. Hal tersebut dirasakan oleh Daneal yang juga secara sadar dan sukarela tetap berada di komunitas JPR.

"Jelas mas, selama saya masih main Pokemon Go sih tapi ya semoga juga Niantic selalu bikin perubahan supaya pemain Pokemon Go ga bosan. Banyak hal positif yang saya dapatkan, jadi ga ada alasan saya untuk keluar dari JPR."

Hal senada juga dirasakan oleh Fajar yang ingin tetap bertahan di dalam komunitas JPR selama masih memainkan game Pokemon Go.

"Selama game Pokemon Go masih ada, selama itu juga gua bakalan tetap ada di JPR, tapi kecuali kalo gua ga pindah rumah ke luar kota juga ya. Haha. Ya walaupun begitu sih selama masih bisa bertahan disini, kenapa ga. Banyak manfaat yang gua dapat disini."

Sesuai dengan nilai yang ada pada teori pertukaran sosial ini, jumlah anggota komunitas JPR meningkat setelah mereka mencoba untuk memanfaat media sosial di antaranya Instagram dan grup Whatsapp. Lili pun mengungkapkan bahwa komunitas JPR menjadi makin bertambah semenjak mereka memutuskan untuk menggunakan Instagram dan grup Whatsapp sebagai wadah mereka untuk melakukan komunikasi kelompok di antara para anggota JPR.

"Awalnya komunitas ini cuma ada 5 orang, ga nyangka akhirnya sekarang udah banyak yang gabung, saat ini jumlah anggota JPR udah lebih dari 200 orang."

Hal tersebut membuktikan bahwa komunitas JPR telah berhasil memanfaatkan media sosial seperti Instagram dan grup Whatsapp mulai dari membentuk, mengonstruksi pesan, hingga melakukan komunikasi kelompok sehingga makin hari komunitas JPR semakin berkembang dan dikenal di kalangan dunia game Pokemon Go khususnya di Indonesia. Tidak dapat dipungkiri bahwa sejatinya media sosial sangat penting untuk pembentukan dan keberlangsungan sebuah komunitas virtual, hal ini dikarenakan media sosial merupakan wadah yang memang digunakan manusia untuk "berselancar" di dunia virtual.

\section{Simpulan}

Berdasarkan pada hasil dari penelitian yang telah dilakukan dan juga pembahasan yang telah dijelaskan oleh peneliti, maka dapat diambil kesimpulan bahwa: pertama, proses terjadinya pembentukan sebuah komunitas virtual Jakarta Pogo Raiders (JPR) berangkat dan dilatarbelakangi oleh kesamaan pada minat atau hobi seluruh anggotanya terhadap game Pokemon Go. Atas dasar kesamaan tersebut, mereka berinisiatif untuk membuat komunitas JPR yang dapat menjadi sarana para pemain Pokemon Go yang berdomisili dan bekerja di wilayah Jakarta untuk dapat melakukan interaksi dan berkomunikasi.

Kedua, komunitas JPR memanfaatkan media sosial seperti Instagram dan grup Whatsapp sebagai media komunitas dalam melakukan komunikasi kelompok. Pemanfaatan media sosial Instagram dan grup Whatsapp dianggap tepat dan juga 
Pemanfaatan Virtual Community Sebagai Media Komunikasi Kelompok Game Pokemon Go (JPR) Melalui Media Sosial

sangat efektif. Instagram merupakan media sosial yang masih menjadi populer sebagai media promosi dan informasi dalam menarik perhatian sehingga memudahkan para pemain Pokemon Go menemukan komunitas JPR. Sedangkan grup Whatsapp dimanfaatkan untuk mengonstruksi pesan dan melakukan pertukaran informasi antar anggota yang telah tergabung di dalam komunitas JPR. Komunikasi kelompok dilakukan setiap harinya dengan cara anggotaikan informasi dan update mengenai game Pokemon Go, grup Whatsapp juga menjadi sarana untuk saling mengenal antar sesama anggota sehingga komunikasi kelompok dapat berjalan dengan efektif di dalamnya.

Ketiga, keberhasilan JPR dalam memanfaatkan media sosial sebagai media komunikasi kelompok ditandai dengan kenyamanan yang dirasakan anggota untuk tetap berada dan tergabung di dalam komunitas JPR. Secara sadar dan sukarela mereka bergabung dengan komunitas JPR dengan memperhitungkan keuntungan yang telah didapatkan selama berada di dalam komunitas tersebut. Keberhasilan lainnya ditandai dengan semakin banyaknya jumlah anggota komunitas yang bergabung dengan JPR hingga saat ini.

Penelitian ini diharapkan dapat anggotaikan kontribusi bagi perkembangan ilmu komunikasi khususnya perkembangan media sosial sebagai media atau wadah bagi para komunitas virtual dalam melakukan komunikasi kelompok antar anggota kelompok di dalamnya. Penelitian ini juga diharapkan dapat menjadi bukti bahwa tidak hanya komunitas nyata yang dapat melakukan komunikasi kelompok, komunitas virtual juga dapat melakukan hal serupa dengan memanfaatkan kemajuan teknologi yaitu media sosial. Peneliti berharap media sosial dapat menjadi media atau wadah bagi berbagai macam komunitas virtual lainnya, untuk dapat memanfaatkan teknologi terutama media sosial dalam melakukan komunikasi kelompok sehingga keberlangsungan komunitas tetap terjaga sekalipun sulit untuk melakukan pertemuan di dunia nyata.

\section{Ucapan Terima Kasih}

Peneliti mengucapkan terima kasih kepada seluruh pihak yang telah membantu dalam proses pembuatan penelitian ini. Di antaranya komunitas Jakarta Pokemon Go Raider yang bersedia menjadi informan. Tidak lupa juga ucapan terima kasih kepada redaksi dari Jurnal Komunikasi, Fakultas Ilmu Komunikasi Universitas Tarumanegara atas kesempatannya dalam berbagi hasil penelitian ini. Terakhir ucapan terima kasih kepada orang tua dan keluarga terutama istri dan anak untuk semangat dan doanya yang sangat berarti bagi peneliti.

\section{Daftar Pustaka}

Astutir, U. D., \& Lestari, I. (2019). Dampak Pemasaran Online Terhadap Perilaku Pembelian Konsumen Studi Kasus Mahasiswa Ekonomi Angkatan 2017 Universitas Tidar Magelang. Jurnal Online Mahasiswa Manajemen, 1(1).

Edosomwan, S., Prakasan, S. K., Kouame, D., Watson, J., \& Seymour, T. (2011). The History of Social Media and its Impact on Business. The Journal of Applied Management \& Entrepreneurship, 16(3), 79-91. 
Hakim, L. N. (2013). Ulasan Metodologi Kualitatif: Wawancara Terhadap Elit. Pusat Pengkajian, Pengolahan Data Dan Informasi (P3DI) Sekretariat Jenderal DPR RI, 4(2), 165-172.

Hidayanti, R., \& Yahya, M. (2017). Peran Media Baru Dalam Membentuk Komunitas Virtual. Jurnal Ilmiah Mahasiswa FISIP Unsyiah, 2, 47-66.

Iqbal, M. (2021). Pokémon GO Revenue and Usage Statistics (2020). Www.Businessofapps.Com.

https://www.businessofapps.com/data/pokemon-go-statistics/

Linarwati, M., Fathoni, A., \& Minarsih, M. M. (2016). Studi Deskriptif Pelatihan Dan Pengembangan Sumberdaya Manusia Serta Penggunaan Metode Behavioral Event Interview Dalam Merekrut Karyawan Baru Di Bank Mega Cabang Kudus. Journal of Management, 2(2), 1.

Lubis, F. O., Lubis, F. M., \& Arindawati, W. A. (2019). Aktivitas Komunikasi Komunitas Pokemon Go Club Karawang. Jurnal Politikom Indonesiana, 4(2), 40-48.

Muhammad, R., \& Manalu, R. (2017). Analisis Pemanfaatan Virtual community sebagai Media Komunikasi Kelompok melalui Media Sosial. Interaksi Online, 5(4), 1-11.

Perdana, I. H. (2018). Pokemon Go Sebagai Saluran Komunikasi Pemasaran Alternatif. Ultimacomm, 9(1), 1-17.

Permassanty, T. D., \& Muntiani, M. (2018). Strategi Komunikasi Komunitas Virtual dalam Mempromosikan Tangerang Melalui Media Sosial. Jurnal Penelitian Komunikasi, 21(2), 173-186.

Prasetyo, D., \& Irwansyah. (2020). Memahami Masyarakat Dan Perspektifnya. Jurnal Manajemen Pendidikan Dan Ilmu Sosial, 1(1), 163-175.

Pratnyawan, A. (2019). Masih Banyak yang Main, Pokemon GO Tembus 1 Miliar Download. Www.Hitekno.Com. https://www.hitekno.com/games/2019/08/02/060000/masih-banyak-yangmain-pokemon-go-tembus-1-miliar-download

Prayugo, D. W. (2018). Pengaruh Komunitas Virtual Terhadap Minat Beli Online Pada Grup Facebook Bubuhan Samarinda. EJurnal Ilmu Komunikasi Universitas Mulawarman, 6(1), 143-157.

Pyrko, I., Dörfler, V., \& Eden, C. (2017). Thinking together: What makes Communities of Practice work? Human Relations, 70(4), 389-409.

Rahayu, T., Syafril, S., Wekke, I. S., \& Erlinda, R. (2019). Teknik Menulis Review Literatur Dalam Sebuah Artikel Ilmiah. University of Chicago Press.

Rohayati. (2017). Proses Komunikasi Masyarakat Cyber Dalam. Jurnal RISALAH, 28(1), 43-54.

Situmorang, J. R. (2012). Pemanfaatan Internet Sebagai New Media Dalam Bidang Politik, Bisnis, Pendidikan Dan Sosial Budaya. Jurnal Administrasi Bisnis, 8(1), 77-91.

Steverzwijn. (2019). Creating A Healthy Pokémon GO Community. Www.Pokemongohub.Net. https://pokemongohub.net/post/article/opinion/healthy-pokemoncommunity-guide-to-happiness/ 
Yudha Pradhana:

Utilization of Virtual Community as a Communication Media For Pokemon Go Game Group (JPR) Using Social Media

Pemanfaatan Virtual Community Sebagai Media Komunikasi Kelompok Game Pokemon Go (JPR) Melalui Media Sosial

Tutiasri. (2016). Komunikasi Dalam Komunikasi Kelompok. CHANNEL: Jurnal Komunikasi, 4(1), 81-90.

Utami, L. S. S. (2015). Teori-Teori Adaptasi Antar Budaya. Jurnal Komunikasi Universitas Tarumanegara, 7(2), 180-197. 